\title{
Appearance of infectious hematopoietic necrosis virus (IHNV) and neutralizing antibodies in sockeye salmon Onchorynchus nerka during their migration and maturation period
}

\author{
G. S. Traxler ${ }^{1, *}$, J. R. Roome ${ }^{1}$, K. A. Lauda ${ }^{2}$, S. LaPatra ${ }^{2}$ \\ 'Department of Fisheries and Oceans, Biological Sciences Branch, Pacific Biological Station, Nanaimo, \\ British Columbia, Canada V9R $5 \mathrm{~K} 6$ \\ ${ }^{2}$ Clear Springs Foods Inc., Buhl, Idaho 83316, USA
}

\begin{abstract}
The appearance of infectious hematopoietic necrosis (IHN) virus and the presence of neutralizing antibodies were determined in a population of adult sockeye Oncorhynchus nerka salmon during their spawning migration. Both. IHN virus and neutralizing antibodies were detected in sockeye salmon while still in sea water This is the first reported finding of the virus in wild salmonids in the marine environment and suggests the possibility of a marine host or reservoir. The possibility of vertical or egg-associated transmission was investigated by crossing adults with different titers of IHN virus and also by exposing these gametes to the virus to increase the chances of infecting progeny. Vertical transmission of IHN virus was not observed in eggs or fry from the crosses of $1 \mathrm{HN}$ infected broodfish, even when eggs were water-hardened in the presence of the virus.
\end{abstract}

KEY WORDS: Sockeye salmon - Oncorhynchus nerka Infectious hematopoietic necrosis virus - Vertical transmission $\cdot$ Neutralizing antibodies $\cdot$ Sea water

\section{INTRODUCTION}

Infectious hematopoietic necrosis (IHN) virus is enzootic in sockeye salmon populations in the Pacific Northwest of North America but the epizootiology of the virus in salmonids is still not well understood. Under certain conditions the virus can cause high losses in both wild and enhanced stocks of sockeye salmon Onchorhyncus nerka (Williams \& Amend 1976. Pilcher \& Fryer 1980, Traxler \& Rankin 1989). Both the prevalence and intensity of infection with this rhabdovirus can vary annually within the same sockeye stock (Mulcahy et al. 1983). Despite its virulence and the extensive distribution of the virus in sockeye salmon, sockeye are a highly productive species of salmon in British Columbia, Canada. The virus is gen-

-E-mail: traxlerg@pbs.dfo.ca erally only isolated from juvenile salmon with clinical infections and from sexually mature adults (Mulcahy et al. 1982). However, losses due to IHN virus in 2-yr-old kokanee $O$. nerka (non-anadromous sockeye) have been reported (Traxler 1986). The biology of the virus in sockeye populations is still a matter of conjecture, with the source of the virus infecting different life stages of the salmon still unknown. It is felt that fry become infected with the virus by either vertical or egg-associated transmission from adults or by direct exposure to the virus from freshwater reservoirs. Field observations have suggested that the virus can be vertically transmitted from adult spawners to their progeny (Mulchay \& Pascho 1985, Meyers et al. 1990), but this method of transmission has yet to be proved experimentally. Further, research by Yoshimizu et al. (1989) indicates that the virus is unlikely to survive inside the egg. While intraovum infection is unlikely, transmis- 
sion on the surface of the eggs, or contamination of equipment may explain the reported observations of vertical transmission (Plumb 1972, Holway \& Smith 1973, Wolf et al. 1973, Carlisle et al. 1979). Little is known about the potential of vertical transmission of IHN virus in spawning populations; however, it is felt to occur infrequently in large-scale hatchery operations (Meyers et al, 1990). The virus is easily transmitted in both fresh water and sea water from fish to fish by waterborne exposure (Wolf 1988, Traxler et al. 1993)

The question as to the source of IHN virus in adult sockeye salmon is also unresolved. Early studies showed that the virus could be recovered from survivors of an IHN infection as juveniles when the fish matured (Amend 1975). This study, along with the fact that virus had not been isolated from sockeye during the marine phase, led to the hypothesis that survivors of an infection became lifelong carriers, with the virus reappearing as the fish underwent maturation and subsequent deterioration of the immune system (Mulcahy et al. 1984). However, the establishment of a carrier state or viral latency in salmon has proved difficult to confirm. Rhabdoviruses are not characteristically latent, and the possibilities of virus latency or the existence of a carrier state have not been resolved in sockeye salmon. More recently, a report by Drolet et al. (1995) suggested that the virus is maintained in salmon populations by the presence of defective interfering (DI) particles. They speculate that levels of infectious virus are kept below detection limits by the presence of particles resembling DI particles and that titers of infectious virus increase during spawning. On the other hand, a study by Amos et al. (1989) suggested that returning adult sockeye do not carry IHN virus latently but become infected with the virus upon returning to fresh water. This study along with the finding of IHN virus in freshwater aquatic invertebrates (Shors \& Winston 1989, Yamamoto et al. 1989, Mulchay et al. 1990) suggested the presence of a freshwater host or reservoir. Despite extensive efforts to identify a freshwater source of JHN virus, no host has been implicated in the transmission of the virus. The mechanisms involved in the transmission and persistence of IHN virus in a feral population of salmon are likely to be complex and involve several age groups and possible reservoirs. Studies to determine the role of these factors in the life cycle of IHN virus are important in developing strategies to reduce the impact of the virus on salmon populations.

It is generally assumed that sexually maturing Pacific salmon approaching spawning are incapable of producing antibodies, thus leading to the many bacterial and fungal infections often seen at the end of their life cycle (Mulchay et al. 1984). Neutralizing antibod- ies against IHN virus produced by adult rainbow trout were first reported by Amend \& Smith (1974). Recent advances in the sensitivity and specificity of serological tests have resulted in the use of these tests in epizootiological studies (LaPatra in press). Serological and virus isolation tests were conducted on adult sockeye salmon during their migration and maturation period to determine whether a correlation exists between the presence of infectious virus and the production of neutralizing antibodies to IHN virus in maturing fish. The use of serological tests combined with virus isolations may help answer questions regarding the life cycle of IHN virus in sockeye salmon.

Experiments were also conducted to determine whether vertical or egg associated transmission of IHN virus could be demonstrated under laboratory conditions.

\section{MATERIAL AND METHODS}

Study area. During the fall of 1991 and 1992 adult sockeye salmon returning to spawn in Great Central Lake on the west coast of Vancouver Island, British Columbia, Canada, were sampled at various locations throughout their migration (Fig. 1). In 1991, the fish were sampled from 2 freshwater sites: from site $A$, located on Stamp River at the entrance to Great Central Lake, and from the spawning grounds (site B). The following year 2 additional marine sites were included and samples were collected from Barkley Sound and the Alberni Inlet.

Sampling procedure and viral assay. Captured fish were euthanized with a blow to the head and identified with a number so that serum samples could be matched with tissue samples for virology. Blood obtained from individual fish by caudal peduncle puncture was kept at $4{ }^{\circ} \mathrm{C}$, allowed to clot and centrifuged at $3000 \times \mathrm{g}$ for $10 \mathrm{~min}$. The serum was removed and stored at $-80^{\circ} \mathrm{C}$ until required for the neutralization tests. Anterior kidney tissue was removed from each fish, and sampling instruments were disinfected by immersing in $70 \%$ ethanol and flaming between each fish. Tissues were kept at $4^{\circ} \mathrm{C}$ and tested for the presence of IHN virus within $24 \mathrm{~h}$ of collection using the plaque assay method of Burke \& Mulchay (1980). The tissue samples were diIuted 1:10 with Earle's balanced salt solution and homogenized with a Polytron generator (Brinkman Instuments Co., Rexdale, Ontario, Canada). Homogenates were centrifuged for $10 \mathrm{~min}$ at $2000 \times g$ and 10 -fold serial dilutions of the supernatants were inoculated on preformed monolayers of epithelioma papillosum cyprini cells. The cultures were fixed and stained after 7 to $10 \mathrm{~d}$ incubation at $15^{\circ} \mathrm{C}$. Plaques were counted and 


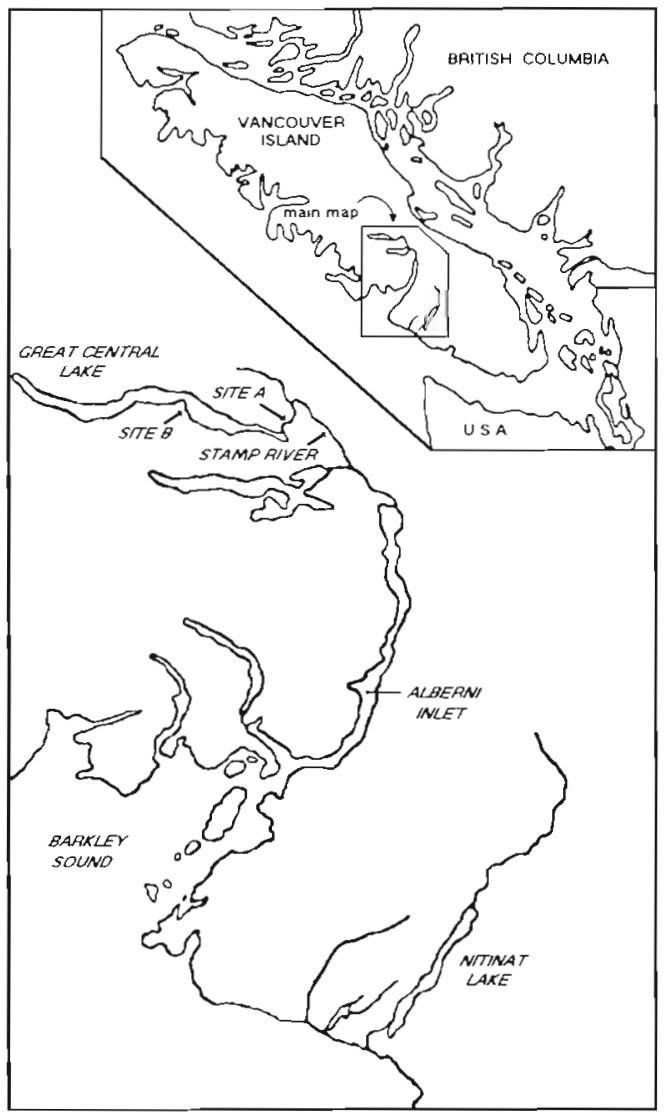

Fig. 1. Sampling sites. Vancouver Island, BC, Canada

viral titers calculated as plaque-forming units per gram (pfu g ${ }^{-1}$ ) of tissue.

Neutralizing titers. Serum from each fish was tested for the presence and titer of neutralizing antibodies to IHN virus using a plaque reduction method (LaPatra et al. 1993). Two-fold serial dilutions of sera in Hank's balanced salt solution were tested for neutralizing activity by reacting with an equal volume of a standard quantity of IHN virus for $30 \mathrm{~min}$ at $18^{\circ} \mathrm{C}$. Fresh serum containing complement was obtained from diseasefree rainbow trout and added to the test wells. The antibody titer was reported as the reciprocal of the highest dilution that resulted in a $50 \%$ reduction in the number of plaques observed in the negative controls. Fisher's exact test (Sokal \& Rohlf 1981) was used to test the independence between IHN virus neutralizing activity of serum and the prevalence of the virus in maturing sockeye salmon.

Passive immunization. For passive immunization, rainbow trout Oncorhynchus mykiss (mean weight, $1 \mathrm{~g})$ were anesthetized and injected intraperitoneally with $50 \mu$ l of sockeye salmon serum with low (titer, 20) or moderate (titer, 160) IHNV neutralization activity or with saline. An additional group of rainbow trout was injected with hyperimmune rabbit serum made against
IHNV isolate 220-90 (LaPatra et al. 1991). Replicated 25 -fish groups were challenged with $10^{4} \mathrm{pfu} \mathrm{ml}^{-1}$ by standard procedures (LaPatra et al. 1994) and were monitored for $21 \mathrm{~d}$ for deaths. Comparisons between treatments were made after calculating mean cumulative percent mortality.

Fish held to maturation. During October of 1991 and 1992, maturing sockeye captured in a trap located in the Stamp River (site A) were transported to the Pacific Biological Station. The fish were placed in a $4.5 \mathrm{~m}$ circular tank supplied with dechlorinated city water and held until maturation.

Each fish was marked with a Floy tag (Floy Tag and Manufacturing Inc., Seattle, WA, USA), and a serum sample was obtained from it by caudal puncture before placing it into the tank. At maturation, gametes were removed from each fish for a separate experiment, and serum and tissue samples were collected to test for antibody and virus levels.

Vertical transmission. Six pairs of mature sockeye salmon adults, captured in the Stamp River and held at the Pacific Biological Station, were randomly crossed. Virus assays were conducted on hematopoietic tissues and reproductive fluids from each fish. Gametes from each mating were mixed for 2 to $3 \mathrm{~min}$, rinsed once in sterile water to remove organic matter, and divided into 3 equal aliquots. One group from each mating was water-hardened in pathogen-free fish culture water consisting of dechlorinated city water for $1 \mathrm{~h}$. A second group was water-hardened in $100 \mathrm{ppm}$ iodophore for $1 \mathrm{~h}$. The third group from each mating was water-hardened in fish culture water containing $7.4 \times 10^{3} \mathrm{pfu} \mathrm{ml}^{-1}$ of IHN virus. Each group of eggs was placed in a basket with a separate single-pass water supply. Virus testing was conducted on random samples collected from each group periodically during the development of the egg and fry. Developing eggs (10 eggs individually assayed) were tested for IHN virus from each group 3 times prior to hatching, and fry were tested twice after hatching In addition, virus tests were conducted on samples of dead eggs and fry twice during the 4 mo of holding.

\section{RESULTS}

\section{Vertical transmission}

Random matings of the sockeye adults resulted in 3 crosses in which the ovarian fluids had high virus' titers, 1 with medium titer and 2 in which virus was not detected (Table 1). Virus was not detected in milt from any of the males used in the crosses. No virus was detected in any of the eggs or fry from each of the 3 treatments conducted on eggs from each pair. 
Table 1. IHN virus tıters detected in adult sockeye salmon Oncorhynchus nerka and progeny resulting from various pairnngs. Virus titers expressed as plaque-forming units (pfu) per $\mathrm{ml}$ of flund or $\mathrm{g}$ of tissue. nvd: no virus detected

\begin{tabular}{|cccc|}
\hline & $\begin{array}{c}\text { Reproductive } \\
\text { fluid }\end{array}$ & $\begin{array}{c}\text { Kidney/ } \\
\text { spleen }\end{array}$ & $\begin{array}{c}\text { Eggs and } \\
\text { fry }\end{array}$ \\
\hline $\begin{array}{l}\text { Pair 1 } \\
\text { Male }\end{array}$ & nvd & nvd & nvd \\
Female & nvd & $1.0 \times 10^{3}$ & \\
Pair 2 & & & \\
Male & nvd & nvd & nvd \\
Female & $1.5 \times 10^{4}$ & nvd & \\
Pair 3 & & & \\
Male & nvd & nvd & nvd \\
Female & $1.1 \times 10^{6}$ & $n v d$ & \\
Pair 4 & & & \\
Male & nvd & $1.0 \times 10^{2}$ & nvd \\
Female & $9.2 \times 10^{5}$ & $5.8 \times 10^{4}$ & \\
Pair 5 & & & nvd \\
Male & nvd & nvd & \\
Female & nvd & nvd & \\
Pair 6 & & & \\
Male & nvd & $3.0 \times 10^{2}$ & nvd \\
Female & $6.0 \times 10^{6}$ & $2.4 \times 10^{5}$ & \\
\hline
\end{tabular}

\section{Virus concentration and prevalence}

In $1991,7 \%(4 / 60)$ of the sockeye salmon sampled from a trap located in the Stamp River (site A) had IHN virus titers ranging from $4.9 \times 10^{2}$ to $5.6 \times 10^{4}$ (mean $1.4 \times 10^{4}$ ) pfu $\mathrm{g}^{-1}$ of kidney tissue (Table 2). Three of the virus positive fish were female and one was a male. Migrating fish captured on October 10 , 1991 from the trap in the Stamp River, transported and held at Pacific Biological Station (PBS) until maturation, showed an increased prevalence of IHN virus. The prevalence of IHN virus increased during the holding period with the infection level reaching $38 \%$

Table 2. Prevalence of IHN virus in kidney tissue of adult sockeye salmon Oncorhynchus nerka returning in 1991 to spawn in Great Central Lake via Stamp River, BC, Canada PBS: Pacific Bıologicai Station

\begin{tabular}{|lccc|}
\hline Location & Date & $\begin{array}{c}\text { No. positive/ } \\
\text { no. sampled }\end{array}$ & \%ositive \\
\hline $\begin{array}{l}\text { Stamp River } \\
\text { Stamp River } \\
\text { (held at PBS) }\end{array}$ & Sep 10 & $4 / 60$ & 7 \\
Great Central Lake $10^{\circ}$ & Nov 20 & $47 / 42$ & 38 \\
adte fish were captured and transported to the Pacific \\
$\begin{array}{l}\text { Biological Station. Samples for virus assay were collected } \\
\text { when the fish matured }\end{array}$ \\
\hline
\end{tabular}

$(16 / 42)$. Virus titers also increased during this period ranging from $1.0 \times 10^{2}$ to $4.6 \times 10^{6}$ (mean $6.3 \times 10^{5}$ ) pfu $\mathrm{g}^{-1}$ of tissue. Fish sampled from tho spawning grounds had a prevalence of $70 \%(47 / 67)$ with titers ranging from $1.0 \times 10^{2}$ to $3.0 \times 10^{6}$ (mean $\left.1.4 \times 10^{6}\right) \mathrm{pfu} \mathrm{g}^{-1}$ of kidney tissue

In 1992, the prevalence of IHN virus also increased in the population of sockeye salmon during the migration period (Table 3). Samples were obtained on several dates from fish during the saltwater phase of their migration. The samples collected from the Alberni Inlet on September 28, 1992 showed a prevalence of $11 \%(7 / 60)$ positive for IHN virus. Titers of virus present in the kidney tissues ranged from $6.8 \times 10^{3}$ to $9.7 \times$ $10^{5} \mathrm{pfu}^{-1}$ (mean $2.3 \times 10^{5}$ ). IHN virus levels in the fish moved from the trap in the Stamp River to the PBS and held to maturity were $36 \%(20 / 55)$, and titers ranged from $1.0 \times 10^{2}$ to $3.2 \times 10^{6} \mathrm{pfu} \mathrm{g}^{-1}$ (mean $2.1 \times 10^{5}$ ). Spawning fish sampled from the spawning grounds in Great Central Lake had a prevalence of $50 \%(30 / 60)$ with titers ranging from $1.4 \times 10^{2}$ to $1.0 \times 10^{7} \mathrm{pfu} \mathrm{g}^{-1}$ (mean $1.0 \times 10^{5}$ ).

\section{Antibody titers}

In 1991, antibody titers were determined for 20 fish being held at the PBS until maturation. Neutralizing antibody titers were detected in serum samples from $7 / 20$ fish sampled on November 7 (Table 4). Neutralizing titers of 1280 or higher were measured in samples from 3 fish. A second serum sample obtained on December 5 from 7 of the fish revealed that in 2 cases antibody titers increased during the interval between samples. These results show that sexually maturing adult sockeye salmon are capable of producing neutralizing antibodies against IHN virus.

In 1992, antibody titers were detected in serum from 2/60 fish collected from the Alberni Inlet near China Creek. Both fish had neutralizing titers in excess of 160. No other antibody titers were detected until sexually mature fish were tested, either on the spawning grounds in Great Central Lake or those held to maturity at the PBS. None of the fish sampled from the Stamp River had detectable levels of neutralizing antibodies.

Both virus and neutralizing antibody titers were determined from a total of 40 fish held at the PBS (Table 5). Initial serum samples were obtained when the fish were captured and placed in the tanks from October 9 to 16, 1992. Subsequent samples were obtained when the fish had reached sexual maturity approximately 2 mo later on December 14, 1992. A total of 19 fish showed increased antibody levels during the holding period while undergoing maturation. 
Table 3. Prevalence of IHN virus in kidneys of adult sockeye salmon Oncorhynchus nerka returning in 1992 to spawn in Great Central Lake

\begin{tabular}{|c|c|c|c|c|c|}
\hline Location & Date & $\begin{array}{l}\text { No. positive/ } \\
\text { no. sampled }\end{array}$ & $\begin{array}{l}\% \text { positive } \\
\text { IHNV }\end{array}$ & $\begin{array}{l}\text { No. positive for } \\
\text { IHNV antibodies }\end{array}$ & $\begin{array}{l}\% \text { positive } \\
\text { antibodies }\end{array}$ \\
\hline \multicolumn{6}{|l|}{ Salt water } \\
\hline Barkley Sound & Jul 23 & $0 / 60$ & 0 & $0 / 60$ & 0 \\
\hline Alberni Inlet & Jul 28 & $0 / 63$ & 0 & $0 / 63$ & 0 \\
\hline Barkley Sound & Aug 6 & $0 / 120$ & 0 & Not tested & Not tested \\
\hline Alberni lnlet & Sep 28 & $7 / 60$ & 12 & $2 / 60$ & 3 \\
\hline \multicolumn{6}{|l|}{ Fresh water } \\
\hline Stamp River & Sep 22 & $1 / 30$ & 3 & $0 / 30$ & 0 \\
\hline Stamp River & Oct 8 & $1 / 30$ & 3 & $0 / 30$ & 0 \\
\hline Stamp River (held at PBS) & $\operatorname{Oct} 9^{\circ}$ & $20 / 55$ & 36 & $18 / 55$ & 33 \\
\hline Great Central Lake & Nov 20 & $30 / 60$ & 50 & $5 / 60$ & 8 \\
\hline
\end{tabular}

Table 4. Neutralizing antibody titers and IHN virus concentrations in kidney tissue of adult sockeye salmon Oncorhynchus nerka held at the Pacific Biological Station. Fish were captured October 10, 1991 and sampled on November 7. 1991 PNT: plaque neutralization test. Antibody titers are reported as the reciprocal of the highest dilution that resulted in a $50 \%$ reduction in the average number of plaques detected in the negative control wells

\begin{tabular}{|rrrrrrrrr|}
\hline $\begin{array}{c}\text { No. of } \\
\text { fish }\end{array}$ & $50 \%$ PNT & \multicolumn{6}{c|}{ IHN virus titers } & (pfu $\mathrm{g}^{-1}$ tissue) \\
\hline 13 & $<20$ & 8 & 1 & 2 & 1 & 0 & 1 \\
0 & 40 & & & & & & \\
1 & 80 & 1 & & & & & \\
1 & 160 & 1 & & & & & \\
1 & 320 & 1 & & & & & \\
1 & 640 & 1 & & & & \\
1 & 1280 & 1 & & & & \\
2 & 2560 & 1 & 1 & & & \\
\hline
\end{tabular}

Table 5. Frequency of neutralizing IHN antibody and virus titers in adult sockeye salmon Oncorhynchus nerka held at the Pacific Biological Station. Fish were captured October 9 , 1992 and sampled when they matured. PNT: plaque neutralization test. Antibody titers are reported as the reciprocal of the highest dilution that resulted in a $50 \%$ reduction in the average number of plaques detected in the negative control wells

\begin{tabular}{|crrrrrrrr|}
\hline $\begin{array}{c}\text { No. of } \\
\text { fish }\end{array}$ & $50 \%$ PNT & \multicolumn{6}{c|}{ IHN virus titers (pfu $\mathrm{g}^{-1}$ tissue) } \\
\hline 21 & $<20$ & 12 & 4 & 2 & 1 & 1 & 1 \\
5 & 40 & 5 & & & & & \\
2 & 80 & 2 & & & & & \\
1 & 160 & 1 & & & & & \\
2 & 320 & 1 & 1 & & & & \\
0 & 640 & & & & & & \\
9 & $>640$ & 9 & & & & \\
\hline
\end{tabular}

In the group of 19 fish with increased antibody levels only one had detectable levels of IHN virus. In the other group (21 fish), none of which showed increased antibody levels, 9 , or $42 \%$, were IHN virus-positive in kidney tissue with titers ranging from $1.0 \times 10^{2}$ to $3.2 \times$ $10^{6} \mathrm{pfu} \mathrm{g}^{-1}$.

The fish sampled from the spawning grounds showed a similar pattern to those held to maturity at the PBS. In fish on the spawning grounds, IHN virus was tound only in the group of 55 tish lacking detectable antibodies (Table 6). Among the 55 fish lacking detectable antibodies, $55 \%(30 / 55)$ were positive for IHN virus with kidney titers ranging from $1.4 \times$ $10^{2}$ to $1.6 \times 10^{6} \mathrm{pfu}^{-1}$. In the group of 5 fish with neutralizing antibodies, none had detectable levels of IHN virus. Using Fisher's exact test of independence, it was determined that when IHN virus neutralizing activity was detected in serum the prevalence of detectable virus was significantly less $(p<0.001)$ than when antiIHN virus antibodies were absent.

Table 6. Frequency of neutralizing antibody and virus titers in spawning adult sockeye salmon Oncorhynchus nerka from Great Central Lake in 1992. PNT. plaque neutralization test. Antibody titers are reported as the reciprocal of the highest dilution that resulted in a $50 \%$ reduction in the average number of plaques detected in the negative control wells

\begin{tabular}{|crrrrrrr|}
\hline $\begin{array}{c}\text { No. of } \\
\text { fish }\end{array}$ & $50 \%$ PNT & \multicolumn{8}{c|}{ IHN virus titers } & (pfu & \multicolumn{2}{c|}{ tissue) } \\
\hline 55 & $<20$ & 25 & 13 & 8 & 6 & 1 & 2 \\
1 & 40 & 1 & & & & & \\
1 & 80 & 1 & & & & & \\
0 & 160 & & & & & & \\
0 & 320 & & & & & & \\
2 & 640 & 2 & & & & \\
\hline
\end{tabular}




\section{Passive immunization}

Passive immunization of rainbow trout with sockeye salmon serum with low or moderate IHN virus neutralization activity provided dose-dependent protection against IHN virus challenge in agreement with previous studies (LaPatra et al. 1993, 1994). Rainbow trout injected with saline exhibited a mean cumulative mortality of $28 \%(13 / 47)$ whereas rainbow trout injected with sockeye serum with low (titer, 20) and moderate (titer, 160) activity exhibited $6 \%(3 / 50)$ and $0 \%(0 / 50)$ cumulative mortality, respectively. Passive immunization with IHN virus hyperimmune rabbit serurn activity provided complete protection.

\section{DISCUSSION}

All sockeye salmon populations along the Pacific coast of North America examined to date are infected with IHN virus. Although the biology of IHN virus in sockeye salmon has been studied extensively, the source of the virus infecting both fry and adult salmon has remained an unresolved issue for many years. Vertical transmission and the carrier state are important areas in understanding the epizootology of IHN virus in Pacific salmon.

Experiments with IHN virus-infected brood fish did not result in vertical transmission of IHN. Eggs and progeny resulting from such fish appeared virus-free by cell culture, and losses due to IHN virus were not detected in the sac fry. Similarly, eggs water-hardened in the presence of the virus proved virus-free on subsequent testing, and yielded virus-free progeny. These results confirm other recent vertical transmission trials which concluded that vertical transmission was an infrequent event and likely to occur only in large-scale hatchery operations (Engelking et al. 1991, LaPatra et al. 1991). With carefully controlled 'egg take' procedures that observe proper disinfection of equipment and eggs, the risk of IHN virus transmission from parent fish to fry via the egg should be minimal (McDaniel et al. 1994)

Because salmon spend 2 to 3 yr at sea, the opportunity to obtain samples for virological testing from these fish is limited. Our finding of IHN virus in adult sockeye salmon from sea water is the first reported occurrence of the virus in fish during this phase of their life cycle. The levels of virus present in the kidney tissues suggest that viral replication was occurring, and that the virus was present not merely as a covert or latent infection. The fish were approximately 2 mo from spawning and had not yet developed any secondary sex characteristics. It is also interesting that antibodies against IHN virus were detected at this stage of sexual maturation. Based upon the rate of development of neutralizing antibodies in adult salmonids, the presence of humoral antibodies suggests that the virus had been present in these fish for some time. Experimentally, juvenile rainbow trout (mean weight, $16 \mathrm{~g}$ ) exposed to waterborne IHN virus developed detectable neutralization activity in 2 wk; the activity peaked in titer and prevalence at $6 \mathrm{wk}$ post-exposure at $15^{\circ} \mathrm{C}$ (LaPatra et al. 1993). Adult rainbow trout (mean weight, $900 \mathrm{~g}$ ) injected with IHN virus exhibit a similar kinetics of anti-IHN virus antibody formation at the same temperature (LaPatra unpubl. information). Because the immune response of a poikilotherm is temperature dependent, the sockeye salmon could have been exposed to virus up to 5 to 6 mo before sexual maturation. Hattenberger-Baudouy et al. (1995) indicated that antibodies against IHN virus required $14 \mathrm{wk}$ before detection in rainbow trout held at $10^{\circ} \mathrm{C}$.

The finding of IHN virus at concentrations as high as $10^{5} \mathrm{pfu}^{-1}$ in the kidneys of sockeye salmon when still in sea water raises the additional possibility of a marine source or reservoir of the virus (Armstrong et al. 1993). The sockeye may have contracted the virus during their seawater phase from a reservoir or host present in the marine environment. With the recent findings of the North American strain of viral hemorrhagic septicemia (VHS) virus in 2 species of marine fishes (Meyers et al. 1992, 1994, Traxler \& Kieser 1994), and the reports of better survival rates of the fish rhabdoviruses, IHN and VHS, in sea water than in fresh water (Winton et al. 1991), the marine environment may be a possible source of IHN virus to salmonids while in sea water. While the chances of waterborne contact leading to infection seem unlikely because of the tremendous dilution factor in the ocean, it remains a possibility based upon the relative ease of transmission shown by experimental challenges conducted in sea water (Traxler et al. 1993). The ingestion of marine organisms harboring IHN virus is also a possible method of infection, but the virus has not yet been found in marine organisms. It is highly unlikely that the IHN infection occurred from contact with the freshwater runoff into the marine environment, because years of previous studies have resulted in virus isolations only from fish in fresh water at or near sexual maturity (Traxler 1983). Also, the fish were sampled some $15 \mathrm{~km}$ from the mouth of the river and earlier samplings of 183 sockeye salmon conducted in July and 120 fish in August had proved negative for the virus.

The occurrence of IHN virus in farmed Atlantic salmon in British Columbia during the past several years also suggests the possibility of a marine source of the virus. It is unJikely that the Atlantic salmon smolts are infected with the virus while in fresh water 
because the hatcheries that produce smolts do not use surface water or are located on streams not accessible to anadromous fish. Also, IHN virus has not been detected in routine viral monitoring of Atlantic salmon pre-smolts. There has been speculation that migrating sockeye salmon adults or juveniles may serve as a source of IHN virus for farmed Atlantic salmon and that sea lice may act as a vector to transmit the virus to the farmed fish. However, it is doubtful that adult sockeye salmon are a source of the infection for farmed salmon because the finding of IHN virus in adult sockeye salmon in sea water seems to be a rare event. Migrating adult sockeye salmon have been tested for IHN virus on a number of occasions and have always turned out to be free of the virus (Traxler 1983, Mulcahy et al. 1984, Amos et al. 1989). Infected juvenile sockeye salmon migrating past Atlantic salmon farms are a possible source of IHN virus because clinically infected smolts migrating from lakes into the ocean have on occasion been reported (Burke \& Grischkowsky 1984, Follett \& Burton 1995). However, this possibility warrants further investigation because sockeye smolts migrating to sea normally appear healthy. Virological testing of marine organisms in and around netpens should also be conducted because, as mentioned before, a marine organism may be the reservoir of the virus.

Acknowledgements. The authors thank DI T P. T. Evelyn for his critical review of the paper.

\section{LITERATURE CITED}

Amend DF (1975) Detection and transmission of infectious hematopoietic necrosis virus rainbow trout. J Wildl Dis 11. $471-478$

Amend DF, Smith L (1974) Pathophysiology of infectious hematopoietic necrosis (IHN) virus disease in rainbow trout (Salmo gairdneri): early changes in blood and aspects of the immune response after injection of IHN virus. J Fish Res Bd Can 31:1371-1378

Amos KH, Hopper KA, LeVander L (1989) Absence of infectious hematopoietic necrosis virus (IHNV) in adult sockeye salmon. J Aquat Anim Health 1:281-282

Armstrong R, Robinson J, Rymes C. Needham I (1993) Infectious hematopoietic necrosis in Atlantic salmon in British Columbia. Can Vet. J 34:312-313

Burke JA, Grischkowsky RS (1984) An eipzootic caused by infectious hematopoietic necrosis virus in an enhanced population of sockeye salmon, Oncorhynchus nerka (Walbaum), smolts at Hidden Creek, Alaska. J Fish Dis 7 : $421-429$

Burke JA, Mulcahy D (1980) Plaquing procedure infectious hematopoietic necrosis virus. Appl Environ Microbiol 39: $872-876$

Carlisle JC, Schat KA, Elston R (1979) Infectious hematopoietic necrosis in rainbow trout Salmo gairdneri Richardson in a semi-closed system. J Fish Dis 2:511-517

Drolet BS, Chiou PP, Heidel J, Leong J (1995) Detection of truncated virus particles in a persistent RNA virus infec- tion in vivo. J Virol 69:2140-2147

Engelking HM, Kaufman J, Groberg WJ, LaPatra SE (1991) Vertical transmission and covert infection studies of infectious hematopoeitic necrosis vırus. In: Fryer JL (ed) Second International Symposium on Viruses of Lower Vertebrates. July 29-31, 1991 Oregon State University, Corvallis, Oregon, p 253-261

Follett JE, Burton TO (1995) Epizootics of infectious hematopoietic necrosis virus in an enhanced population of sockeye salmon Oncorhynchus nerka smolts at Chenik Lake, Alaska. Alsk Dep Fish Res Bu] 2:137-142

Hattenberger-Baudouy AM, Danton $M$, Merle $G$, de Kinkelon P (1995) Serum neutralization test for epidemiological studies of salmonid rhabdoviruses in France. Vet Res (Paris) 26:512-520

Holway JE, Smith CE (1973) Infectious hematopoietic necrosis of rainbow trout in Montana: a case report. J Wildl Dis 9:287-290

LaPatra SE (in press) The use of serology in virus surveillance and certification of fin fish. Ann Rev Fish Dis

LaPatra SE, Groberg WJ, Rohovec JS, Fryer JL (1991) Delayed fertilization of steelhead (Oncorhynchus mykiss) ova to investigate vertical transmission of infectious hematopoietic necrosis virus. In: Fryer JL (ed) Second International Symposium on Viruses of Lower Invertebrates. July 29-31, 1991. Oregon State University, Corvallis, Oregon, p 261-269

LaPatra SE, Lauda KA, Jones GR, Walker SC, Shewmaker WD (1994) Development of passive immunotherapy for contol of infectious hematopoietic necrosis. Dis Aquat Org 20:1-6

LaPatra SE, Turner T, Lauda KA, Jones GR, Walker S (1993) Characterization of the humoral response of rainbow trout to infectious hematopoietic necrosis virus. J Aquat Anim Health 5:165-171

McDaniel TR, Pratt KM, Meyer TR, Ellison TD, Follelt JE, Burke JA (1994) Alaska sockeye salmon culture manual. Special Fish Rept No. 6. Alaska Dept Fish and Game, Juneau

Meyers TR, Short S, Lipson K, Batts WN, Winton JR, Wilcock J, Brown E (1994) Association of viral hemorrhagic septicemia virus with epizootic hemorrhages of the skin in Pacific herring Clupea harengus pallasi from Prince William Sound and Kodiak Island, Alaska, USA. Dis Aquat Org 19:27-37

Meyers TR, Sullivan J, Emmenegger E, Follett J, Short S, Batts WN, Winton JR (1992) Identification of viral hemorrhagic septicemia virus isolated from Pacific cod Gadus macrocephalus in Prince William Sound, Alaska, USA. Dis Aquat Org 12:167-175

Meyers TR, Thomas JB, Follett JE, Saft RR (1990) Infectious hematopoietic necrosis virus:trends in prevalence and the risk management approach in Alaskan sockeye salmon culture. J Aquat Anim Health 2:85-98

Mulcahy D, Burke J, Pascho R, Jenes C K (1982) Pathogenesis of infectious hematopoietic necrosis virus in adult sockeye salmon (Oncorhynchus nerka). Can J Fish Aquat Sci 39: 1144-1149

Mulcahy D, Jenes CK, Pascho R (1984) Appeatance and quantification of infectious hematopoietic necrosis virus in female sockeye salmon (Oncorhynchus nerka) during their spawning migration. Arch Virol 80:171-181

Mulcahy D, Klaybor D, Batts WN (1990) Isolation of infectious hematpoietic necrosis virus from a leech (Piscicola salmositica) and a copepod (Salmincola sp.), ectoparasites of sockeye salmon Oncorhynchus nerka. Dis Aquat Org 8: $29-34$ 
Mulcahy D, Pascho RJ (1985) Vertical transmission of infectious hematopoietic necrosis virus in sockeye salmon, Oncorhynchus nerka (Walbaum): isolation of virus from dead eggs and fry. J Fish Dis 8:383-396

Mulcahy D, Pascho RJ, Jenes CK (1983) Titre distribution patterns of infectious haematopoietic necrosis virus in ovarian fluids of hatchery and feral salmon populations. J Fish Dis 6:183-188

Pilcher KS, Fryer JL (1980) The viral diseases of fish: a review through 1978. Part 1: Diseases of proven viral etiology. CRC Crit Rev Microbiol 7:287-363

Plumb JA (1972) A virus-caused epizootic of rainbow trout (Salmo gairdneri) in Minnesota. Trans Am Fish Soc 101: $121-123$

Shors ST, Winston V (1989) Detection of infectious hematopoietic necrosis virus in an invertebrate (Callibaetis sp). Am J Vet Res 50:1307-1309

Sokal RR, Rohlf FJ (1981) Biometry. WH Freeman and Co., New York

Traxler GS (1983) A survey for infectious hematopoietic necrosis virus in adult sockeye salmon (Oncorhynchus nerka) in Great Central Lake, British Columbia. Can Tech Rep Fish Aquat Sci 1205

Traxler GS (1986) An epizootic of infectious hematopoietic necrosis in 2-yr-old kokanee. Oncorhynchus nerka (Walbauml at Lake Cowichan. British Columbia. J Fish Dis 9. $545-549$

Traxler GS, Kieser D (1994) Isolation of the North American strain of viral hemorrhagic septicemia virus (VHSV) from herring (Clupea harengus pallasi) in British Columbia. Am Fish Soc Newsl (Fish Health Sect) 22(1):8

Traxler GS, Rankin JB (1989) An infectious hematopoietic

Responsible Subject Editor: J. Leong, Corvallis, Oregon, USA necrosis epizootic in sockeye salmon Oncohrynchus nerka in Weaver Creek spawning channel, Fraser River system, BC. Canada. Dis Aquat Org 6:221-226

Traxler GS, Roome JR, Kent ML (1993) Transmission of infectious hematopoietic necrosis virus in sea water. Dis Aquat Org 16:111-114

Williams I, Amend DF (1976) A natural epizootic of infectious hematopoietic necrosis in fry of sockeye salmon (Oncorhynchus nerka) at Chilko Lake. British Columbia. J Fish Res Bd Can 35:875-879

Winton JR, Batts WN, Deering RE, Brunson R, Hopper K, Nishizawa T, Stehr C (1991) Characteristics of the first North American isolates of viral hemorrhagic septicemia virus. In: Fryer JL (ed) Second International Symposium on Viruses of Lower Vertebrates. July 29-31, 1991. Oregon State University, Corvallis, Oregon, p 43-51

Wolf $K$ (1988) Infectious hematopoietic necrosis. In: Wolf $K$ (ed) Fish viruses and fish viral diseases. Cornell University Press, Ithaca, $\mathrm{p}$ 83-114

Wolf K, Quimby MC, Pettijohn LL, Landolt ML (1973) Fish viruses: isolation and identification of infectious hematopoietic necrosis in eastern North America. J Fish Res Bd Can 30:1625-1627

Yamamoto T, Arakawa CK, Batts WN, Winton JR (1989) Comparisons of infectious hematopoietic necrosis in natural and experimental infections of spawning salmonids by infectivity and immunohistochemistry. In: A.hne W, Kurstak E (eds) Viruses of lower vertebrates. Springer, Berlin, p $411-429$

Yoshimizu M, Sami M, Kimura T (1989) Survivability of infectious hematopoietic necrosis virus in fertilized eggs of masu and chum salmon. J Aquat Anim Health 1:13-20

Manuscript first received: May 31, 1996

Revised version accepted: August 29, 1996 